\title{
ANALISIS RASIO KEUANGAN UNTUK MENGUKUR KINERJA KEUANGAN KOPERASI SIMPAN PINJAM DUA MUARA KOTA MANNA TAHUN 2015-2017
}

\author{
Erwin Febriansyah, Ade Tiara Yulinda, Diah Purnamasari \\ Program Studi Akuntansi Fakultas Ekonomi Universitas Muhammadiyah Bengkulu \\ Program Studi Manajemen Fakultas Ekonomi Universitas Muhammadiyah Bengkulu \\ erwinfebriansyah@gmail.com; ade91tiarayulinda@gmail.com; Diahpurnamasari094@gmail.com
}

\begin{abstract}
ABSTRAK
Erwin Febriansyah, Ade Tiara Yulinda, Diah Purnamasari; Tujuan dari penelitian ini penelitian ini adalah untuk mengetahui kinerja keuangan Koperasi Simpan Pinjam Dua Muara Kota Manna tahun 20152017 dilihat dari rasio likuiditas,rasio solvabilitas,dan rasio profitabilitas.Objek penelitian ini adalah laporan keuangan Koperasi Simpan Pinjam Dua Muara Tahun 2015-2017. Jenis penelitian ini menggunakan penelitian deskriptif kuantitatif yaitu mengumpulkan,mengolah dan menginterprestasikan data yang diperoleh sehingga dapat memberi gambaran yang jelas mengenai keadaan yang diteliti, menggunakan rumus-rumus keuangan.Hasil analisis terhadap laporan Keuangan koperasi Simpan Pinjam Dua Muara Kota Manna dengan menggunakan analisis rasio keuangan sudah cukup baik. Sehingga dapat disimpulkan bahwa kinerja keuangan Koperasi Simpan Pinjam Dua Muara Kota Manna sudah cukup baik tetapi perlu dilakukan perbaikan perhitungan terhadap laporan keuangannya.
\end{abstract}

\section{ABSTRACT}

Erwin Febriansyah, Ade Tiara Yulinda, Diah Purnamasari; The formulation of the problem in this study is how financial performance of Dua Muara of saving loan cooperative in the city of manna in 20152017 seen from ratio liquidity, solvency and provability.The purpose of this study is to determine financial performance of simpan pinjam cooperative in the city of manna in 2015-2017 seen from ratio liquidity, solvency and provability.The object of this researchis the Financial report of Dua Muara of saving loan cooperative in the city of manna in 2015-2017. Data analysis technique used in this reseach are quantitative descriptive and interpretating of the data so that it can give Clear description under study Using financial formulation. The result of analysis trough financial report of Dua Muara of saving loan cooperative using financial are report good enough. So it can be conclude that financial performance of of Dua Muara of saving loan cooperative are good enough but it is necessary to improve the calculation of the financial statement

Key Words: Financial Ratio, Financial Performance, Savings and Loan Cooperative

\section{LATAR BELAKANG}

Kondisi perekonomian Indonesia secara umum berada di fase yang fluktuatif. Hal ini terlihat pada tahun 2015 pertumbuhan ekonomi hanya berada di angka 4,8 persen. Hal ini sedikit banyak mempengaruhi sektor perekonomian di Indonesia, menurunnya kepercayaan para pebisnis, dan hilangnya selera untuk ekspansi bisnis. Selama ini perekonomian Indonesia sendiri telah ditopang dengan adanya eksistensi koperasi. Tidak satu lembaga sejenis lainnya yang mampu menyamai koperasi, tetapi diharapkan menjadi penyeimbang terhadap pilar ekonomi lainnya (Bambang:2015).

Lembaga koperasi oleh banyak kalangan, diyakini sangat sesuai dengan budaya dan tata kehidupan bangsa Indonesia. Di dalamnya terkandung muatan menolong diri sendiri, kerjasama untuk kepentingan bersama (gotong royong), dan beberapa esensi moral lainnya. Dengan adanya koperasi diharapkan dapat menopang perekonomian Indonesia baik saat perekonomian menurun dan perekonomian stabil. Hal ini terkandung dalam tujuan dasar ekonomi Indonesia, yaitu pasal 33 Undang- Undang Dasar 1945.Dalam koperasi juga terdapat pos-pos keuangan yang nantinya digunakan dalam penyusunan pelaporan keuangannya pada rapat anggota tahunan.

Menurut pasal 1 UU No. 25 Tahun 1992, koperasi adalah badan usaha yang beranggotakan orang seorang atau badan hukum koperasi dengan melandaskan kegiatannya berdasarkan prinsip koperasi sekaligus sebagai gerakan ekonomi rakyat yang berdasar atas asas kekeluargaan.

Salah satu analisis untuk membuat perencanaan dan pengendalian keuangan yang baik adalah dengan melakukan analisis rasio keuangan. Rasio keuangan merupakan salah satu bentuk informasi akuntansi yang penting dalam proses penilaian kinerja perusahaan sehingga dengan rasio keuangan 
tersebut dapat mengungkapkan kondisi keuangan suatu perusahaan maupun kinerja yang telah dicapai perusahaan untuk suatu periode tertentu.

Laporan keuangan merupakan suatu alat yang sangat penting bagi para pimpinan perusahaan untuk memperoleh informasi-informasi tentang posisi keuangan perusahaan dan hasil-hasil yang telah dicapai oleh perusahaan selama periode tertentu. Selain itu tujuan utama dari laporan keuangan adalah untuk mengetahui posisi perkembangan keuangan dan operasional perusahaan. Untuk mencapai tujuan tersebut maka perlu dianalisa dan diiterprestasikan agar dapat diketahui kinerja sutu perusahaan, sehingga planning perusahaan tercapai (Bambang:2015).

Anggota koperasi, pengurus koperasi, calon anggota, bank, kreditur, dan pemerintah sangat membutuhkan laporan keuangan sebagai alat pengambilan keputusan sehingga dituntut agar proses pengolahan keuangan dikoperasi dilaksanakan secara profesional dan memerlukamadanyan sistem pertanggungjawaban yang baik (good responsibility) dan informasi yang relevan dapat diandalkan guna pengambilan keputusan (task decision), perencannaan (planning), maupun pengendalian (controlling).

Tujuan utama dari usaha koperasi adalah meningkatkan kesejahteraan anggota pada khususnya dan masyarakat pada umumnya untuk tujuan tersebut tercapai berbagai usaha yang dilakukan suatu koperasi agar bermanfaat dan menguntungkan para anggotanya. Seiring dengan semakin berkembangnya kegiatan usaha koperasi, maka banyak pihak menuntut agar pengelolaan koperasi secara profesional. Pengelolaan secara profesional memerlukan adanya sistem pertanggungjawabkan yang baik baik serta penyajian informasi yang relevan dan dapat diandalkan guna perencanaan, pengendalian, maupun dalam pengambilan keputusan. Informasi yang dibutuhkan oleh pihak-pihak yang berkepentinan di dalam pengambilan keputusan dapat diperoleh melalui informasi informasi yang disajikan oleh pihak manajemen dalam laporan keuangan koperasi, melalui laporan keuangan tersebut akan diketahui posisi keuangan koperasi serta hasil-hasil yang telah dicapai, agar dapat memberikan informasi keuangan yang wajar yang dibutuhkan oleh pihak-pihak yang berkepentingan.

Koperasi Simpan Pinjam Dua Muara merupakan koperasi yang bergerak di bidang jasa simpan pinjam,dimana pada akhir periode akuntansi Koperasi Simpan Pinjam Dua Muara, melakukan perhitungan terhadap laporan keuangan koperasi. Dalam melakukan perhitungan laporan keuangan Koperasi Dua Muara tidak melakukan analisis terhadap laporan keuangan. Mengingat koperasi tidak melakukan analisis maka peneliti tertarik untuk melakukan analisis terhadap lapoan keuangan koperasi tersebut. Salah satu cara yang harus dilakukan untuk menghadapi persaingan ini adalah dengan cara mengevaluasi kinerja yang dapat dilihat dari hasil analisis laporan keuangan setiap tahunya, sehingga dari hasil analisis ini pihak manajemen dapat membuat keputusan-keputusan yang akan diambil untuk meningkatkan usaha koperasi.

Analisa rasio adalah suatu metode analisa untuk mengetahui hubungan dari pos-pos tertentu dalam neraca atau laporan rugi laba secara individu atau kombinasi dari kedua laporan tersebut (Munawir, 2007:37). Analisis rasio merupakan salah satu dari teknik analisis yang dapat memberikan petunjuk yang menggambarkan kondisi koperasi terutama dalam bidang finansialnya. Analisis rasio keuangan merupakan metode analisis yang sering dipakai karena merupakan metode yang paling cepat untuk mengetahui kinerja keuangan koperasi. Analisis rasio keuangan dalam kegiatannya meliputi pengevaluasian aspek-aspek keuangan antara lain adalah tingkat likuiditas, solvabilitas dan profitabilitas (Bambang:2015).

Penggunaan analisis rasio diharapkan dapat mengukur kinerja koperasi khususnya dari hal keuangannya dan juga dapat mengetahui secara langsung perkembangan koperasi melalui laporan keuangan.

Dari semua tujuan tersebut, yang terpenting dari analisis laporan keuangan adalah tujuannya untuk mengurangi ketergantungan para pengambil keputusan pada dugaan murni, terkaan dan intuisi, mengurangi dan mempersempit ruang lingkup ketidakpastian yang tidak bisa dihilangkan pada setiap proses pengambilan keputusan. Analisis laporan keuangan tidaklah berarti mengurangi kebutuhan akan penggunaan pertimbangan-pertimbangan melainkan hanya dasar yang layak dan sistematis dalam menggunakan pertimbangan -pertimbangan tersebut.

Rumusan masalah penelitian ini bagaimana kinerja keuangan Koperasi Simpan Pinjam Dua Muara dilihat dari rasio likuiditas, rasio solvabilitas, dan rasio profitabilitas?. Tujuan penelitian ini untuk mengetahui kinerja keuangan Koperasi Simpan Pinjam Dua Muara Kota Manna Tahun 2015-2017 dilihat dari rasio likuiditas, rasio solvabilitas, dan rasio profitabilitas.

\section{LANDASAN TEORI \\ Koperasi}

Menurut Adenk Sudarwanto (2013: 19), koperasi adalah badan usaha yang beranggotakan orangorang atau badan hokum koperasi dengan melandaskan kegiatanya pada prinsip koperasi sekaligus sebagai gerakan ekonomi fakyat yang berdasarkan asas kekeluargaan. 


\section{Kinerja}

Menurut Irham Fahmi (2011:02) kinerja merupakan hasil yang diperoleh suatu organisasi baik organisasi tersebut bersifat profit oriented dan non profit oriented yang dihasilkan selama satu periode waktu. Secara lebih tegas Amstron dan Baron "mengatakan kinerja merupakan hasil pekerjaan yang mempunyai hubungan kuat dengan tujuan strategis organisasi, kepuasan konsumen dan memberikan kontribusi ekonomi" (Amstrong dan Baron,1998:15). Lebih jauh Indra Bastian mengatakan bahwa "kinerja adalah gambaran mengenai tingkat pencapaian pelaksanaan suatu kegiatan dalam mewujudkan sasaran, tujuan, misi dan visi organisasi yang terutang dalam perumusan skema strategis atau organisasi.

\section{Analisis Kinerja}

Menurut (Sugiyarso, 2011:101) Analisis merupakan suatu proses menelaah masing-masing unsur laporan keuangan, dan menelaah hubungan diantara unsur-unsur tersebut agar memperoleh pengertian, pemahaman yang baik dan tepat atas laporan keuangan suatu badan usaha sebagai evaluasi terhadap bidang organisasi, manajemen usaha, permodalan dan keuangan.

\section{Analisis Rasio Keuangan}

Rasio dalam analisis laporan keuangan adalah angka yang menunjukkan suatu unsur lainnya dalam laporan keuangan. Hubungan antara unsur-unsur laporan keuangan dinyatakan dalam bentuk matematis yang sederhana.

\section{METODOLOGI}

Jenis penelitian ini menggunakan jenis penelitian deskriptif kuantitatif. Penelitian ini akan dilakukan pada Koperasi Simpan Pinjam Dua Muara yang beralamat di Jl.BupatiBaksir Rt. 11 Kec. Kota Manna Kabupaten Bengkulu Selatan. Waktu penelitian dilakukan pada bulan November tahun 2018.Teknik pengumpulan data dengan Observasi, Wawancara dan Dokumentasi. Teknik analisis data yang digunakan dalam penelitian ini deskriptif kuantitatif.

\section{HASIL PENELITIAN DAN PEMBAHASAN \\ Hasil}

Berdasarkan dari penelitian yang telah dilakukan pada Koperasi Serba Usaha "Dua Muara", maka berikut ini adalah hasil dari penelitian tentang kinerja keuangan koperasi berdasarkan rasio keuangan.

1. Rasio Likuiditas

Rasio Lancar (Current Ratio)

Current ratio mengukur kemampuan perusahaan memenuhi hutang jangka pendeknya dengan menggunakan lancarnya (aktiva yang akan berubah menjadi kas dalam waktu satu tahun).

$$
\begin{aligned}
& \text { Current ratio }=\frac{\text { aktiva } \text { tamoar }}{\text { kutang } \operatorname{lameam}} \times 100 \% \\
& \text { Current ratio } 2015=\frac{580,8.18,000}{148.90 \%, 700} \times 100 \%=235,28 \% \\
& \text { Current ratio } 2016=\frac{88 \mathrm{~B}, 442 . \mathrm{B} 00}{160.712000} \times 100 \%=239,82 \% \\
& \text { Current ratio } 2017=\frac{402.06 \% .900}{166.142 .900} \times 100 \%=242,00 \%
\end{aligned}
$$

Tabel 1Perhitungan Current Ratio Koperasi Simpan Pinjam Dua Muara

\begin{tabular}{cccccc}
\hline Tahun & Aktiva lancar & Hutang lancar & $\begin{array}{c}\text { Current } \\
\text { ratio }\end{array}$ & nilai & $\begin{array}{c}\text { Penilaian } \\
\text { kinerja }\end{array}$ \\
\hline 2015 & 350.516 .000 & 148.937 .700 & $235,28 \%$ & 100 & Sangat baik \\
2016 & 385.442 .000 & 160.718 .000 & $239,82 \%$ & 100 & Sangat baik \\
2017 & 402.067 .900 & 166.142 .900 & $242,00 \%$ & 100 & Sangat baik \\
\hline
\end{tabular}

Sumber: data diolah dari laporan keuangan koperasi dua muara 2015-2017

Dari tabel diatas dapat dideskripsikan keadaan kinerja keuangan berdasarkan rasio keuangan Koperasi Simpan Pinjam khususnya Current Ratio adalah sebagai berikut :

a. Tahun 2015 koperasi menghasilkan Current Ratio sebesar 235,28\% yang dimana rasio ini dapat dijelaskan bahwa hutang lancar sebesar Rp. 1,- dijamin aktiva lancar sebesar 235,28. Sehingga, untuk tahun 2015 berdasarkan Peraturan Menteri Negara Koperasi dan Usaha Kecil dan Menengah Republik Indonesia, nomor 06/Per/M.KUKM/V/2006 tanggal 1 Mei 2006 dimana jika $>200 \%$ maka Koperasi Simpan Pinjam "Dua Muara" masuk dalam kriteria yang sangat baik. 
b. Tahun 2016 Current Ratio turun 4,54\% dari tahun sebelumnya, sehingga pada tahun 2016 Current Rationya menjadi 239,82\%, yang dimana rasio ini dapat dijelaskan bahwa hutang lancar sebesar Rp. 1,- dijamin aktiva lancar sebesar 239,82. Sehingga untuk tahun 2016 berdasarkan Peraturan Menteri Negara Koperasi dan Usaha Kecil dan Menengah Republik Indonesia, nomor 06/Per/M.KUKM/V/2006 tanggal 1 Mei 2006 dimana lika $>200 \%$ maka Koperasi Simpan Pinjam "Dua Muara" masuk dalam kriteria yang sangat baik.

c. Tahun 2017 Current Ratio naik 2,18\% dari tahun sebelumnya, sehingga pada tahun 2018 Current Rationya menjadi $242,00 \%$,yang dimana rasio ini dapat dijelaskan bahwa hutang lancar sebesar Rp. 1,-dijamin aktiva lancar sebesar 242,00. Sehingga untuk tahun 2017 berdasarkan Peraturan Menteri Negara Koperasi dan Usaha Kecil dan Menengah Republik Indonesia, nomor 06/Per/M.KUKM/V/2006 tanggal 1 Mei 2006 dimana jika >200\% maka Koperasi Simpan Pinjam "Dua Muara" masuk dalam kriteria yang sangat baik. Peningkatan setiap tahunnya berbeda-beda menunjukkan bahwa peningkatan pada aktiva lancar dan hutang lancar juga berbeda-beda. Peningkatan current ratio terjadi karena aktiva lancar mengalami peningkatan yang besar sedangkan hutang juga mengalami peningkatan.

Besar atau kecilnya peningkatan pada nilai aktiva lancar dapat menyebabkan besar atau kecilnya nilai current ratio. Peningkatan aktiva lancar ini disebabkan oleh jumlah piutang anggotanya yang besar hal ini menunjukkan bahwa piutang anggota memberikan kontribusi yang besar dalam pembayaran hutang jangka pendek koperasi. Piutang anggota ini merupakan tagihan koperasi kepada anggota koperasi,tagihan tersebut timbul karena koperasi memberikan pinjaman uang kepada anggotanya.

Dari analisis data diatas dapat disimpulkan bahwa Current Ratio Koperasi Simpan Pinjam "Dua Muara" pada tahun 2015 - 2017 berada dalam kriteria yang sangat baik karena rata - rata rasionya mencapai sebesar 239,03 .Hal ini dapat diperkuat dengan Peraturan Menteri Negara Koperasi dan Usaha Kecil dan Menengah Republik Indonesia, nomor 06/Per/M.KUKM/V/2006 tanggal 1 Mei 2006 dimana jika $200 \%$ maka Koperasi Simpan Pinjam "Dua Muara" masuk dalam kriteria yang sangat baik.

2. Rasio Solvabilitas

Ratio solvabilitas menunjukkan kemampuan perusahaan untuk memenuhi kewajiban keuangan apabila perusahaan tersebut dilikuidasikan, baik kewajiban jangka pendek maupun jangka panjang. Ratio solvabilitas ini ada beberapa macam yaitu:

a. Rasio antara Hutang dengan aktiva

Ratio ini membandingkan jumlah total hutang dengan total aktiva yang dimiliki koperasi. Dari rasio ini dapat diketahui berapa bagian aktiva yang digunakan untuk menjamin hutang, dengan menggunakan rumus berikut:

\begin{tabular}{|c|c|}
\hline Ratio antara hutang dengan aktiva $=\frac{f \mathrm{~m}}{f \mathrm{~m}}$ & $\frac{\text { and hutamg }}{\text { niah akthas }} \times 100 \%$ \\
\hline Ratio antara hutang dengan aktiva 2015 & $\begin{array}{l}-\frac{815.996000}{422.01, .700} \times 100 \% \\
\quad=74,55 \%\end{array}$ \\
\hline Ratio antara hutang dengan aktiva 2016 & $\begin{array}{c}=\frac{827.171000}{427,942.500} \times 100 \% \\
=71,44 \%\end{array}$ \\
\hline Ratio antara hutang dengan aktiva 2017 & $\begin{array}{l}=\frac{882.896 .900}{474.66^{*} .800} \times 100 \% \\
=70,08 \%\end{array}$ \\
\hline
\end{tabular}

Tabel 2. Total antara hutang dengan aktivaKoperasi Dua Muara

\begin{tabular}{cccccc}
\hline Tahun & Jumlah hutang & Jumlah aktiva & $\begin{array}{c}\text { Ratio antara } \\
\text { hutang dengan } \\
\text { aktiva }\end{array}$ & nilai & $\begin{array}{c}\text { Penilaian } \\
\text { kinerja }\end{array}$ \\
2015 & 315.390 .000 & 423.016 .700 & $74,55 \%$ & 25 & Kurang baik \\
2016 & 327.171 .000 & 457.942 .500 & $71,44 \%$ & 25 & Kurang baik \\
2017 & 332.595 .900 & 474.567 .900 & $70,08 \%$ & 25 & Kurang baik \\
\hline
\end{tabular}

Sumber: data diolah dari laporan keuangan koperasi dua muara tahun 2015-2017 
Dari tabel diatas dapat dideskripsikan keadaan kinerja keuangan berdasarkan rasio keuangan Koperasi Simpan Pinjam khususnya ratio antara hutang dan aktiva adalah sebagai berikut :

a.Tahun 2015 koperasi menghasilkan total rasio hutang dengan modal sendiri sebesar $74,75 \%$ yang dimana rasio ini dapat dijelaskan bahwa setiap Rp.1,- hutang dijamin sebesar Rp 74,75 dari aktiva. Rasio ini menunjukkan sejauh mana hutang dapat ditutupi oleh aktiva, lebih besar rasionya lebih aman (Harahap, 2002:304). Sehingga, untuk tahun 2015 berdasarkan Peraturan Menteri Negara Koperasi dan Usaha Kecil dan Menengah Republik Indonesia, nomor 06/Per/M.KUKM/V/2006 tanggal 1 Mei 2006 dimana jika 6 80\% maka Koperasi Simpan Pinjam "Dua Muara" masuk dalam kriteria yang kurang baik.

b.Tahun 2016 rasio antara hutang dengan aktiva turun sebesar 3,01\% \% dari tahun sebelumnya, sehingga pada tahun 2016 ratio antara hutang dengan aktiva lancar menjadi sebesar 71,44\%, yang dimana rasio ini dapat dijelaskan bahwa setiap Rp. 1,-hutang dijamin sebesar Rp 71,74 dari aktiva. Rasio ini menunjukkan sejauh mana hutang dapat ditutupi oleh aktiva. Sehingga, untuk tahun 2016 berdasarkan Peraturan Menteri Negara Koperasi dan Usaha Kecil dan Menengah Republik Indonesia, nomor 06/Per/M.KUKM/V/2006 tanggal 1 Mei 2006 dimana jika $<$ 80\% maka Koperasi Simpan Pinjam "Dua Muara" masuk dalam kriteria yang kurang baik.

c. Tahun 2017 rasio antara hutang dengan aktiva turun sebesar 1,36\% sehingga pada tahun 2017 koperasi menghasilkan rasio antara hutang dengan aktiva sebesar 70,08\% yang dimana rasio ini dapat dijelaskan bahwa setiap Rp.1,- hutang dijamin sebesar Rp 70,78 dari aktiva. Sehingga, untuk tahun 2017 berdasarkan Peraturan Menteri Negara Koperasi dan Usaha Kecil dan Menengah Republik Indonesia, nomor 06/Per/M.KUKM/V/2006 tanggal 1 Mei 2006 dimana jika $<\mathbf{8 0 \%}$ maka Koperasi Simpan Pinjam "Dua Muara" masuk dalam kriteria yang kurang baik.

Penurunan tiap tahun yang berbeda-beda menunjukkan penurunan pada total hutang dan total aktiva juga berbeda-beda. Penurunan total hutal dengan aktiva ini terjadi karena perbandingan peningkatan antara total hutang dengan total aktiva yaitu total aktiva lebih besar dibandingkan dengan total hutang. Hal ini menunjukkan bahwa total aktiva yang ada mampu membayar jaminan hutang koperasi.

Berdasarkan penjelasan diatas, dapat disimpulkan ratio antara hutang dan aktiva Koperasi Simpan Pinjam "Dua Muara" pada tahun 2015 - 2017 berada dalam kriteria yang buruk karena rata - rata rasionya sebesar 72,09. Hal ini dapat diperkuat dengan Peraturan Menteri Negara Koperasi dan Usaha Kecil dan Menengah Republik Indonesia, nomor 06/Per/M.KUKM/V/2006 tanggal 1 Mei 2006 dimana jika $200 \%$ maka Koperasi Simpan Pinjam "Dua Muara" masuk dalam kriteria yang buruk.

b. Rasio antara hutang dengan modal sendiri

Ratio ini memberikan gambaran bagian dari modal sendiri yang dijadikan jaminan untuk keseluruhan hutang ,rasio ini dihitung dengan rumus:

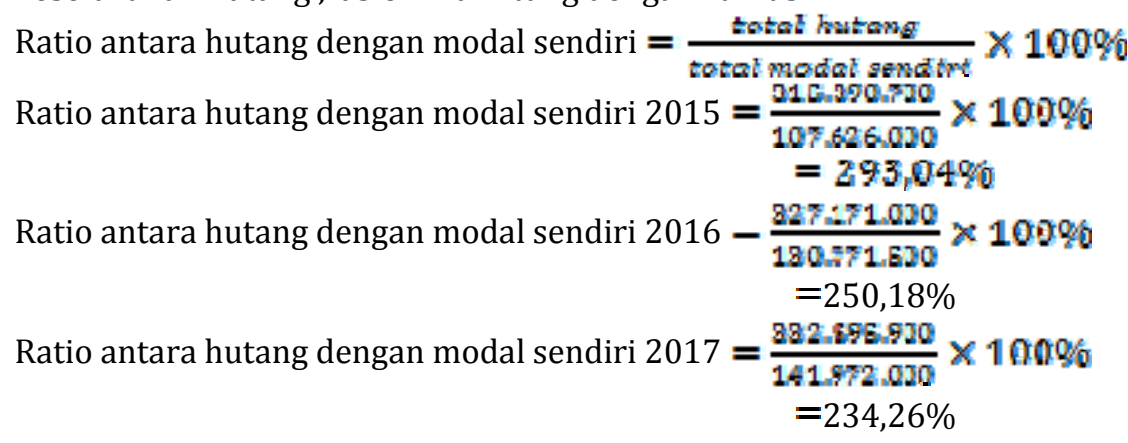

Tabel 3. Perhitungan Ratio Antara Hutang Dengan Modal Sendiri Koperasi Dua Muara

\begin{tabular}{lccccc}
\hline Tahun & $\begin{array}{c}\text { Jumlah } \\
\text { hutang }\end{array}$ & Modal sendiri & $\begin{array}{c}\text { Ratio antara } \\
\text { hutang dengan } \\
\text { modal sendiri }\end{array}$ & nilai & $\begin{array}{c}\text { Peniliaian } \\
\text { kinerja }\end{array}$ \\
\hline 2015 & 315.390 .700 & 107.626 .000 & $293,04 \%$ & 0 & Tidak baik \\
2016 & 327.171 .000 & 130.771 .500 & $250,18 \%$ & 0 & Tidak baik \\
2017 & 332.595 .900 & 141.972 .000 & $234,26 \%$ & 0 & Tidak baik \\
\hline
\end{tabular}

Sumber: data diolah dari laporan keuangan koperasi dua muara 2015-2017 
Dari tabel diatas dapat dideskripsikan keadaan kinerja keuangan berdasarkan rasio keuangan Koperasi Simpan Pinjam khususnya ratio antar total hutang dengan modal,seda sendiri adalah sebagai berikut :

Tahun 2015 koperasi menghasilkan ratio antara hutang dan modal sendiri sebesar 293,04\% yang dimana rasio ini dapat dijelaskan bahwa setiap hutang sebesar Rp. 1,- dijamin dengan modal sendiri sebesar Rp 293,04. Rasio ini menggambarkan sampai sejauh mana modal pemilik dapat menutupi hutang - hutang kepada pihak luar, semakin tinggi rasio ini semakin baik. Dalam penelitian ini modal sendiri koperasi lebih rendah dibandingkan dengan total hutang.

Hal ini terkait dengan skripsi dari Saputro, (2005:24) dimana bila rasio ini menunjukkan jumlah angka rendah maka akan semakin kecil pula jumlah modal sendiri yang digunakan untuk menjamin terbayarnya hutang-hutang perusahaan. Sehingga, pada tahun 2016 berdasarkan Peraturan Menteri Negara Koperasi dan Usaha Kecil dan Menengah Republik Indonesia, nomor 06/Per/M.KUKM/V/2006 tanggal 1 Mei 2006 dimana jika 200\% maka Koperasi Simpan Pinjam "Dua Muara” masuk dalam kriteria yang buruk.

Tahun 2016 rasio antara hutang dan modal sendiri turun sebesar 6,64\% dari tahun sebelumnya, sehingga pada tahun 2016 rasio antara hutang dan modal sendiri menjadi sebesar 250,18\% yang dimana rasio ini dapat dijelaskan bahwa setiap hutang sebesar Rp. 1,- dijamin dengan modal sendiri sebesar 250,18. Rasio ini menggambarkan sampai sejauh mana modal pemilik dapat menutupi hutang - hutang kepada pihak luar, semakin tinggi rasio ini semakin baik. Pada tabel diatas menunjukkan modal sendiri turun sedangkan total hutang meningkat, hal ini membuat modal sendiri koperasi masih belum dapat untuk menutupi hutang-hutang yang ada. Sehingga, pada tahun 2017 berdasarkan Peraturan Menteri Negara Koperasi dan Usaha Kecil dan Menengah Republik Indonesia, nomor 06/Per/M.KUKM/V/2006 tanggal 1 Mei 2006 dimana jika 20 200\% maka Koperasi Simpan Pinjam “Dua Muara” masuk dalam kriteria yang buruk.

Tahun 2017 rasio hutang dengan modal sendiri turun sebesar 1,592\% dari tahun sebelumnya, sehingga pada tahun 2017 totalrasio hutang menjadi sebesar 234,26\% yang dimana rasio ini dapat dijelaskan bahwa setiap hutang sebesar Rp. 1,- dijamin dengan modal sendiri sebesar 234,26 . Rasio ini menggambarkan sampai sejauh mana modal pemilik dapat menutupi hutang hutang kepada pihak luar, semakin tinggi rasio ini semakin baik. Pada tabel diatas menunjukkan modal sendiri turun sedangkan total hutang meningkat, hal ini membuat modal sendiri koperasi masih belum dapat untuk menutupi hutang-hutang yang ada. Sehingga, pada tahun 2017 berdasarkan Peraturan Menteri Negara Koperasi dan Usaha Kecil dan Menengah Republik Indonesia, nomor 06/Per/M.KUKM/V/2006 tanggal 1 Mei 2006 dimana jika $200 \%$ maka Koperasi Simpan Pinjam "Dua Muara” masuk dalam kriteria yang buruk.

Berdasarkan penjelasan diatas, dapat disimpulkan ratio antara hutang dan modal sendiri Koperasi Simpan Pinjam "Dua Muara" pada tahun 2015 - 2017 berada dalam kriteria yang buruk karena rata - rata rasionya sebesar 259,16. Hal ini dapat diperkuat dengan Peraturan Menteri Negara Koperasi dan Usaha Kecil dan Menengah Republik Indonesia, nomor 06/Per/M.KUKM/V/2006 tanggal 1 Mei 2006 dimana jika 20 200\% maka Koperasi Simpan Pinjam "Dua Muara” masuk dalam kriteria yang buruk.

3. Ratio Profitabilitas

Ratio ini mengukur kemampuan perusahaan menghasilkan keuntungan (profitabilitas) pada tingkat penjualan asset, dan modal tertentu.

Ada beberapa cara untuk menghitung profitabilitas,yaitu:

a. Return on Asset (ROA)

Rasio ini mengukur kemampuan perusahaan menghasilkan laba bersih berdasarkan tingkatinvestmen tertentu. Ratio ini bisa dihitung dengan rumus:

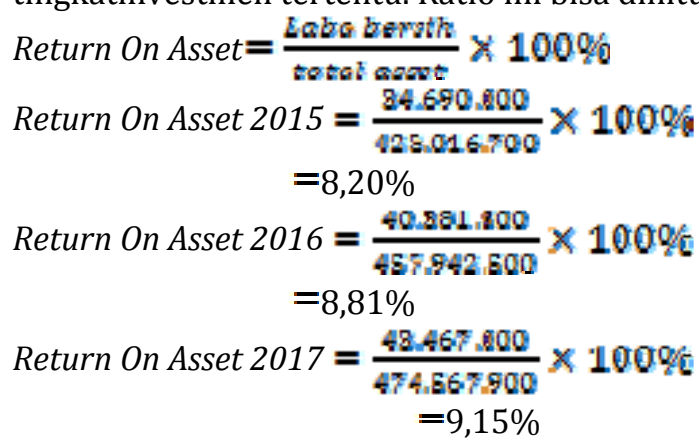


Tabel 4. Perhitungan Ratio Return On Asset

\begin{tabular}{llcccc}
\hline Tahun & Laba bersih & Total Asset & Return On Asset & nilai & Penilaian kinerja \\
\hline 2015 & 34.690 .000 & 423.016 .700 & $8,20 \%$ & 75 & Baik \\
2016 & 40.381 .500 & 457.942 .500 & $8,81 \%$ & 75 & Baik \\
2017 & 43.467 .000 & 474.567 .900 & $9,15 \%$ & 75 & Baik \\
\hline
\end{tabular}

Sumber: data diolah dari laporan keuangan Koperasi Dua Muara 2015-2017

Dari tabel diatas dapat dideskripsikan keadaan kinerja keuangan berdasarkan rasio keuangan Koperasi Simpan Pinjam khususnya Return On asset adalah sebagai berikut :

a. Tahun 2015 koperasi menghasilkan Return On asset sebesar 8,20\% yang berarti setiap Rp. 1,- aset menghasilkan keuntungan Rp 8,20. Rasio ini menunjukkan kemampuan perusahaan menghasilkan laba dari aktiva yang dipergunakan. Semakin tinggi rasio ini maka semakin efektif penggunaan total aktiva dalam menghasilkan laba (Saputro, 2005:24). Sehingga, pada tahun 2015 berdasarkan Peraturan Menteri Negara Koperasi dan Usaha Kecil dan Menengah Republik Indonesia, nomor 06/Per/M.KUKM/V/2006 tanggal 1 Mei 2006 dimana jika 7\%- $\alpha_{m} 10 \%$ maka Koperasi Simpan Pinjam Dua Muara masuk dalam kriteria yang baik.

b. Tahun 2016 Return On asset meningkat sebesar 0,61\% dari tahun sebelumnya, sehingga pada tahun 2016 Return On Investment nya menjadi sebesar 8,81\% yang berarti setiap Rp. 1,- aset menghasilkan keuntungan Rp 8,81. Rasio ini menunjukkan kemampuan perusahaan menghasilkan laba dari aktiva yang dipergunakan. Semakin tinggi rasio ini maka semakin efektif penggunaan total aktiva dalam menghasilkan laba. Sehingga, pada tahun 2016 berdasarkan Peraturan Menteri Negara Koperasi dan Usaha Kecil dan Menengah Republik Indonesia, nomor 06/Per/M.KUKM/V/2006 tanggal 1 Mei 2006 dimana jika 7\% - <10\% maka Koperasi Simpan Pinjam Dua Muara masuk dalam kriteria yang baik.

c. Tahun 2017 Return On asset meningkat sebesar 0,34\% dari tahun sebelumnya, sehingga pada tahun 2016 Return On Investment nya menjadi sebesar 9,15\% yang berarti setiap Rp. 1,- aset menghasilkan keuntungan Rp 9,15. Rasio ini menunjukkan kemampuan perusahaan menghasilkan laba dari aktiva yang dipergunakan. Semakin tinggi rasio ini maka semakin efektif penggunaan total aktiva dalam menghasilkan laba.Sehingga, pada tahun 2017 berdasarkan Peraturan Menteri Negara Koperasi dan Usaha Kecil dan Menengah Republik Indonesia, nomor 06/Per/M.KUKM/V/2006 tanggal 1 Mei 2006 dimana jika 7\%- < 10\% maka Koperasi Simpan Pinjam Dua Muara masuk dalam kriteria yang baik.

Meningkatnya Sisa Hasil Usaha disebabkan karena bertambahnya nominal pendapatan dan menurunkan pengeluaran sedangkan total aktiva juga ikut meningkat karena bertambahnya aktiva lancar dan aktiva tetap. Sehingga, pada tahun 2017 berdasarkan Peraturan Menteri Negara Koperasi dan Usaha Kecil dan Menengah Republik Indonesia, nomor 06/Per/M.KUKM/V/2006 tanggal 1 Mei 2006 dimana jika $7-110 \%$ maka Koperasi Simpan Pinjam "Dua Muara" masuk dalam kriteria yang sangat baik.

Berdasarkan penjelasan diatas, dapat disimpulkan Return On asset Koperasi Simpan Pinjam "Dua Muara" pada tahun 2015 - 2017 berada dalam kriteria yang baik karena rata - rata rasionya sebesar 8,72\%. Hal ini dapat diperkuat dengan Peraturan Menteri Negara Koperasi dan Usaha Kecil dan Menengah Republik Indonesia, nomor 06/Per/M.KUKM/V/2006 tanggal 1 Mei 2006 dimana jika 7 - < 10\% maka Koperasi Simpan Pinjam "Dua Muara" masuk dalam kriteria yang sangat baik.

b. Return On Equity (ROE)

Ratio ini menetukan tingkat pengembalian pada ekuitas. ROE adalah ukuran dari besarnya jumlah laba sebuah perusahaan yang dihasilkan dalam satu tahun terakhir dibandingkan dengan nilai ekuitasnya. Ratio ini bisa dihitung dengan rumus:

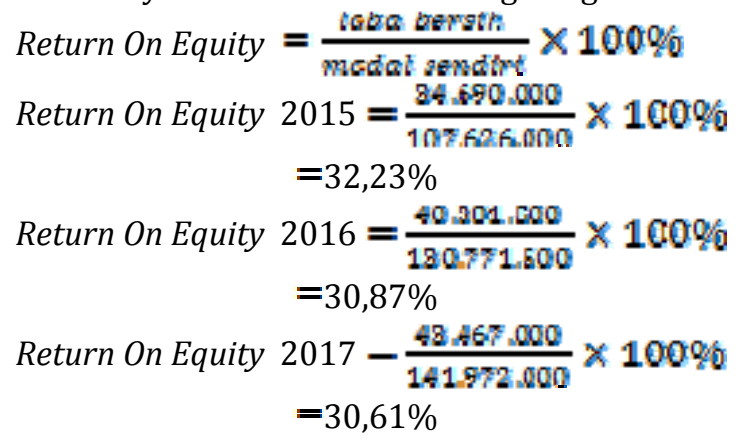


Tabel 5. Perhitungan Ratio Return On Equity

\begin{tabular}{llcccl}
\hline Tahun & Laba bersih & Modal sendiri & $\begin{array}{c}\text { Return On } \\
\text { Equity }\end{array}$ & nilai & Penilaian kinerja \\
\hline 2015 & 34.690 .000 & 107.626 .000 & $32,23 \%$ & 100 & Sangat baik \\
2016 & 40.381 .500 & 130.771 .500 & $30,87 \%$ & 100 & Sangat baik \\
2017 & 43.467 .000 & 141.972 .000 & $30,61 \%$ & 100 & Sangat baik \\
\hline
\end{tabular}

Sumber: data diolah dari laporan keuangan koperasi Dua Muara 2015-2017

Dari tabel diatas dapat dideskripsikan keadaan kinerja keuangan berdasarkan rasio keuangan Koperasi Simpan Pinjam khususnya Return On Equity adalah sebagai berikut :

a. Tahun 2016 koperasi menghasilkan Return On Equity sebesar 32,23\% yang berarti setiap Rp. 1,modal menghasilkan keuntungan Rp 32,23.Rasio ini menunjukkan kemampuan koperasi dengan modal sendiri yang bekerja didalamnya untuk menghasilkan keuntungan. Sehingga, pada tahun 2016 berdasarkan Peraturan Menteri Negara Koperasi dan Usaha Kecil dan Menengah Republik Indonesia, nomor 06 /Per/ M.KUKM /V/2006 tanggal 1 Mei 2006 dimana jika 21\% maka Koperasi Simpan Pinjam "Dua Muara" masuk dalam kriteria yang sangat baik. Hal ini juga diperkuat oleh teori Kasmir, 2017:204 dimana semakin tinggi rasio ini, semakin baik. Artinya posisi pemilik perusahaan semakin kuat, demikian pula sebaliknya.

b. Tahun 2016 Return On Equity turun sebesar 1,36\% dari tahun sebelumnya, sehingga pada tahun 2017 Return On Equitynya menjadi sebesar 30,87\% yang berarti setiap Rp. 1,- modal menghasilkan keuntungan Rp.30,87. Rasio ini menunjukkan kemampuan koperasi dengan modal sendiri yang bekerja didalamnya untuk menghasilkan keuntungan. Menurunnya Sisa Hasil Usaha disebabkan karena berkurangnya nominal pendapatan dan meningkatnya pengeluaran sedangkan modal sendiri juga ikut menurun karena berkurangnya sisa hasil usaha yang terdapat pada modal sendiri. Meskipun sisa hasil usaha dan modal sendiri menurun tetapi hasil dari perhitungan Return On Equity pada tahun 2017 berdasarkan Peraturan Menteri Negara Koperasi dan Usaha Kecil dan Menengah Republik Indonesia, nomor 06 /Per/M .KUKM/V/2006 tanggal 1 Mei 2006 dimana jika $21 \%$ maka Koperasi Simpan Pinjam "Dua Muara" masuk dalam kriteria yang sangat baik.

c. Tahun 2017 Return On Equity turun sebesar 0,26\% dari tahun sebelumnya, sehingga pada tahun 2017 Return On Equitynya menjadi sebesar 30,61\% yang berarti setiap Rp. 1,- modal menghasilkan keuntungan Rp. 30,61. Rasio ini menunjukkan kemampuan koperasi dengan modal sendiri yang bekerja didalamnyauntuk menghasilkan keuntungan. Menurunnya Sisa Hasil Usaha disebabkan karena berkurangnya nominal pendapatan dan meningkatnya pengeluaran sedangkan modal sendiri juga ikut menurun karena berkurangnya sisa hasil usaha yangterdapat pada modal sendiri. Meskipun sisa hasil usaha dan modal sendiri menurun tetapi hasil dari perhitungan Return On Equity pada tahun 2017 berdasarkan Peraturan Menteri Negara Koperasi dan Usaha Kecil dan Menengah Republik Indonesia, nomor 06 /Per/M .KUKM/V/2006 tanggal 1 Mei 2006 dimana jika 2 21\% maka Koperasi Simpan Pinjam "Dua Muara” masuk dalam kriteria yang sangat baik.

Berdasarkan penjelasan diatas, dapat disimpulkan Return On Equity Koperasi Simpan Pinjam "Dua Muara” pada tahun 2015 - 2017 berada dalam kriteria yang sangat baik karena rata rata rasionya sebesar 31,21\%. Hal ini dapat diperkuat dengan Peraturan Menteri Negara Koperasi dan Usaha Kecil dan Menengah Republik Indonesia, nomor 06/Per/M.KUKM/V/2006 tanggal 1 Mei 2006 dimana jika $21 \%$ maka Koperasi Simpan Pinjam "Dua Muara" masuk dalam kriteria yang sangat baik.

\section{Pembahasan}

Tabel 6. Analisis Rasio Keuangan Koperasi Simpan Pinjam DUA MUARA tahun 2015-2016

\begin{tabular}{|c|c|c|c|c|}
\hline \multirow[t]{2}{*}{ No } & \multirow[t]{2}{*}{ Komponen } & \multicolumn{3}{|c|}{ Analisis Ratio (\%) } \\
\hline & & 2017 & 2016 & 2015 \\
\hline 1 & $\begin{array}{l}\text { Likuiditas } \\
\text { a.Current Ratio }\end{array}$ & 242,00 & 239,82 & 235,28 \\
\hline 2 & $\begin{array}{l}\text { Solvabilitas } \\
\text { a. Ratio Antara Hutang dengan Aktiva } \\
\text { b.Ratio Antara Hutang dengan Modal Sendiri }\end{array}$ & $\begin{array}{l}70,08 \\
234,26\end{array}$ & $\begin{array}{l}71,44 \\
250,18\end{array}$ & $\begin{array}{l}74,55 \\
293,04\end{array}$ \\
\hline 3 & $\begin{array}{l}\text { Profitabilitas } \\
\text { a. Return On Investment } \\
\text { b.Return On Equity }\end{array}$ & $\begin{array}{l}9,15 \\
30,61\end{array}$ & $\begin{array}{l}8,81 \\
30,87\end{array}$ & $\begin{array}{l}8,20 \\
32,23\end{array}$ \\
\hline
\end{tabular}

Sumber: data diolah dari laporan keuangan koperasi dua muara tahun 2015-2017 
Hasil analisis tersebut dapat dijadikan sebagai acuan sebagai dasar perkembangan rasio dari tahun

2015-2017.

\section{Rasio Likuiditas}

Rasio likuiditas menunjukan kemampuan suatu koperasi untuk memenuhi kewajiban-kewajiban keuangan yang harus segera dipenuhi atau kemampuan koperasi untuk memenuhi kewajiban keuangan tepat pada saat ditagih. Koperasi yang dapat memenuhi kewajibannya pada saat ditagih disebut liquid,sedangkan yang tidak dapat memenuhi kewajibannya tepat waktu disebut illikuid.

a. Current Ratio

Koperasi Simpan Pinjam Dua Muara pada kurun waktu 3 tahun yaitu dari tahun 2015-2017 memiliki angka rasio lancar berturut-turut yaitu 235,23\%,239,82\% dan 240,00\% dimana ketiga angka rasio tersebut menunjukkan kriteria yang sangat baik,ini disebabkan oleh kemampuan koperasi untuk membayar hutang jangka pendeknya.

\section{Rasio Solvabilitas}

Rasio solvabilitas menunjukan kemampuan koperasi untuk memenuhi kewajiban jangka pendek maupun jangka panjang. Koperasi disebut solvabel apabila koperasi mempunyai aktiva atau kekayaan yang cukup untuk membayar semua hutang-hutangnya. Sedangkan koperasi yang tidak mempunyai aktiva atau kekayaan yang cukup untuk membayar semua hutang-hutangnya disebut insovabel.

a. Ratio antara hutang dengan aktiva

Koperasi Simpan Pinjam Dua Muara pada kurun waktu 3 tahun yaitu dari tahun 2015-2017 memiliki ratio antara hutang dan aktiva berturut-turut sebesar $74,55 \%, 71,44 \%$ dan $70,08 \%$ dimana ketiga angka tersebut menunjukkan kriteria yang kurang baik. Hal ini disebabkan karena asset koperasi tidak mampu memberikan kontribusi yang lebih terhadap total hutang yang dimiliki koperasi. Hasil analisis tersebut menunjukkan bahwa kinerja keuangan koperasi Simpan Pinjam Dua Muara tidak memiliki kekayaan yang cukup untuk membayar hutang-hutangnya.

b. Ratio antara hutang dan modal sendiri

Koperasi Simpan Pinjam Dua Muara pada kurun waktu 3 tahun yaitu dari tahun 2015-2017 memiliki ratio antara hutang dan aktiva berturut-turut sebesar 293,04\%,250,18\%dan 234,26\% dimana ketiga angka tersebut menunjukkan kriteria yang kurang baik.Hal ini disebabkan karena asset koperasi tidak mampu memberikan kontribusi yang lebih terhadap total hutang yang dimiliki koperasi. Hasil analisis tersebut menunjukkan bahwa kinerja keuangan koperasi Simpan Pinjam Dua Muara tidak memiliki kekayaan yang cukup untuk membayar hutang-hutangnya.

\section{Rasio Profitabilitas}

Rasio profitabilitas diukur berdasarkan tingkat kesuksesan koperasi dan kemampuan koperasi dalam menggunakan aktivanya secara produktif. Dengan demikian profitabilitas atau koperasi dapat diketahui dengan memperbandingkan laba bersih yang diperoleh dalam satu periode dengan total asset atau modal koperasi.

a. Return On Asset (ROA)

Koperasi Simpan Pinjam Dua Muara pada kurun waktu 3 tahun yaitu dari tahun 2015-2017 memiliki ratio antara hutang dan aktiva berturut-turut sebesar 8,20\%,8,81\%dan 9,15\% dimana ketiga angka tersebut menunjukkan kriteria penilaian kinerja yang baik. Hal ini disebabkan karena koperasi mampu meningkatkan penggunaan aktivanya secara lebih produktif sehingga mampu menghasilkan laba bersih yang maksimal, dengan kata lain koperasi menunjukkan profitabilitas yang baik.

b. Return On Equity (ROE)

Analisis Return On Equity (ROE) pada koperasi Simpan Pinjam Dua Muara pada tahun 2015-2017 menghasilkan rasio yang berturut-turut $32,23 \%, 30,87 \%$ dan $30,61 \%$ dimana ketiga angka tersebut menunjukkan kriteria yang sangat baik. Hasil analisis tersebut menunjukkan bahwa modal yang dimiliki koperasi sangat rentable dalam menghasilkan laba bersih yang maksimal.

Tabel 7. Rekapitulasi Hasil Analisis Rasio Keuangan Koperasi Simpan Pinjam DUA MUARA tahun 2015-2017

\begin{tabular}{|c|c|c|c|c|c|c|c|}
\hline \multirow[t]{2}{*}{ No } & \multirow[t]{2}{*}{ Komponen rasio } & \multicolumn{2}{|c|}{2017} & \multicolumn{2}{|c|}{2016} & \multicolumn{2}{|r|}{2015} \\
\hline & & Nilai & Kinerja & Nilai & Kinerja & Nilai & Kinerja \\
\hline 1 & Current ratio & 100 & Sangat baik & 100 & Sangat baik & 100 & Sangat baik \\
\hline 2 & Rasio antara hutang dengan aktiva & 25 & Kurang baik & 25 & Kurang baik & 25 & Kurang baik \\
\hline 3 & Rasio antara hutang dengan modal sendiri & 0 & Tidak baik & 0 & Tidak baik & 0 & Tidak baik \\
\hline 4 & Return On Asset (ROA) & 75 & Baik & 75 & baik & 75 & Baik \\
\hline 5 & Return On Investment (ROI) & 100 & Sangat baik & 100 & Sangat baik & 100 & Sangat baik \\
\hline \multicolumn{2}{|c|}{ Jumlah } & 300 & & 300 & & 300 & \\
\hline \multicolumn{2}{|c|}{ Hasil kinerja } & 60 & Cukup baik & 60 & Cukup baik & 60 & Cukup baik \\
\hline
\end{tabular}


Dari tabel tersebut data-data yang telah diolah menunjukkan bahwa kinerja keuangan Koperasi Simpan Pinjam Dua Muara pada tahun 2015-2017 berada dalam kategori yang cukup baik sesuai dengan Pedoman Penilaian Berprestasi Berdasarkan Peraturan Menteri Negara Koperasi Danu Usaha Kecil Menengah Nomor : 06/Per/M.KUKM/V/2006.

\section{KESIMPULAN}

1. Likuiditas Koperasi Simpan Pinjam Dua Muara Kota Manna sangat baik atau liquid. Kewajiban jangka pendeknya dapat dipenuhi tepat pada waktunya.

2. Tingkat solvabilitas Koperasi Simpan Pinjam Dua Muara Kota Manna kurang baik atau insovabel.

3. Kemampuan Koperasi Simpan Pinjam Dua Muara Kota Manna dalam menghasilkan laba (profitabilitas) sangat baik, ini disebabkan adanya kenaikan laba dari tahun sebelumnya.

\section{SARAN}

1. Tingkat likuiditas Koperasi Simpan Pinjam Dua Muara Kota Manna pada tahun 2015-2017 sudah sangat baik atau likuid, maka untuk tahun yang akan datang bias dipertahankan atau ditingkatkan agar tidak terjadi kemunduran dalam keuangan.

2. Tingkat solvabilitas Koperasi Simpan Pinjam Dua Muara Kota Manna tahun 2015-2017 kurang baik atau solvable,maka pihak koperasi perlu menambahkan modal agar Koperasi dapat melunasi hutanghutangnya.

3. Dalam menghasilkan labanya Koperasi Simpan Pinjam Dua Muara Kota Manna pada tahun 20152017 sudah sangat baik,ini disebabkan adanya peningkatan dalam pendapatan setiap tahunnya dan untuk tahun yang akan datang diharapkan koperasi bias meningkatkan labanya.

\section{DAFTAR PUSTAKA}

Adenk Sudarwanto.(2013). Akuntansi Koperasi,pendekatan praktek penyusunan laporan keuangan. Yogyakarta: Graha Ilmu.

Amstrong, M. and Baron,A.(1998).perfomance Management-The New Realities. London:Institute of Personnel and Development.

Bambang Tri Atmodjo, (2015). Analisis Rasio Keuangan Untuk Menilai Kinerja Keuangan Pada KPRI Bina Sejahtera Setda Kabupaten Semarang. Tesis. Semarang: Universitas Negeri Semarang.

Sugiyarso, G. (2011). Akuntansi Koperasi. Yogyakarta: CAPS 